\title{
Effect of Internal Control Systems on Financial Performance of Public Universities in Kenya
}

\author{
Daniel K. Mungai (Corresponding author) \\ School of Business and Economics, Kirinyaga University \\ PO box 143, 10300 Kerugoya \\ Tel: +254722641811 E-mail: dmungai@kyu.ac.ke \\ Mary Maina \\ School of Business and Economics, Kirinyaga University \\ PO box 143, 10300 Kerugoya \\ Tel: +254722641811 E-mail: dmungai@kyu.ac.ke \\ James N. Kungu \\ School of Business and Economics, Laikipia University \\ P.O Box 1100, 20300 Nyahururu \\ Tel: +254722641811 E-mail: dmungai@kyu.ac.ke
}

\begin{abstract}
Most public Universities across the world have reported suboptimal financial performance compared to private universities. The poor financial performance can be attributed to financial management practices. The sound financial management practices require the institutions to have robust internal control systems. However, there are limited empirical research findings regarding the relationship between the internal control systems and financial performance in public universities in Kenya. The general objective of the study was to establish the effect of internal control systems on financial performance of public universities in Kenya. The study specific objective was to investigate the effect of detective controls on the financial performance of public universities in Kenya. The study was anchored on agency theory, stewardship theory, systems theory and attribution theory. The study adopted a causal research design. The target population of respondents were the deputy vice chancellors finance, registrar finance and administration, ICT personnel, finance officers and internal auditors in the 37 public universities in Kenya. The target population was 185 respondents. The study worked with a sample of 34 public universities through stratified random sampling, and the other three were used for pilot testing. Primary data was collected from sample population using semi-structured questionnaires. Secondary data was collected through evaluation of reports, organizational journals, publications and review of information from the organizations website. Quantitative data was analyzed using Statistical Package for Social Sciences (SPSS). All the questionnaires received were referenced and items in the questionnaire coded to facilitate data entry. After data cleaning which entailed checking for errors in entry, descriptive statistics and frequencies were estimated for all the variables and information presented inform of tables, graphs and pie charts. Descriptive statistics and inferential statistics were used because they enabled the researcher to meaningfully describe distribution of scores or measurements using a few indices. Inferential data analysis was done using Pearson Correlation coefficient and regression analysis. Regression analysis was conducted to empirically determine whether detective controls were significant in determining the financial performance of public universities in Kenya. Regression results indicated the goodness of fit for the regression between detective controls and financial performance was strong.

From the regression model, detective controls and financial performance to a constant zero, financial performance would be 3.132. It was established that a unit increase in detective controls would cause an improvement in financial performance by a factor of 0.237 . This clearly showed that there was a positive relationship between detective controls and financial performance. P-value was less than 0.05 , which showed that variables covered in the study on detective controls were statistically significant to influence financial performance. The study concluded that detective controls had a positive and significant influence on the financial
\end{abstract}


performance of public universities in Kenya.

Keywords: Internal control Systems, Detective Controls, Financial Performance

DOI: $10.7176 /$ RJFA/12-16-09

Publication date:August $31^{\text {st }} 2021$

\section{Introduction}

\subsection{Background of the Study}

Every system of internal control has weaknesses on its effectiveness. These include the possibility of mistakes, personnel may circumvent the system through conspiracy and other means. Management is in a position to supersede control procedures by directly distorting transactions or by ordering a subordinate to do so and conditions may change over time so that existing controls may become weak. Internal control measures document transactions by creating an audit trail by limiting the actions of employees through requiring authorization, approval and verification of selected transactions (Mungaya, Mbwambo, \& Tripathi, 2012). They segregate duties because certain job responsibilities are mutually incompatible and, if left unchecked, allow one person too much unsupervised access to organizations assets (Vian, 2012). These internal controls are classified as either preventive, detective, corrective or budgetary controls.

Detective controls form the next level of defence and are strategies, techniques, and procedures designed to recognize and expose undesirable events that escape preventive controls (Monday, Inneh, \& Ojo, 2014). In public universities, detective controls are used to disclose specific types of errors in the system by comparing actual incidences to pre-established standards. When the detective control identifies a departure from standard, it sounds a distress alarm to attract attention to the problem. These detective controls are used by auditors and accountants in public universities before processing transactions and posting to the books, and assist in recalculating the total value of different situations using the price and quantity to avoid an error in the totals (Nyongesa, 2014).

Financial performance is a subjective measure of how well an organisation can use assets and other resources on its disposal from its primary mode of operations and generate revenues (Nyakundi, Nyamita, \& Tinega, 2014). A number of benchmark indicators can be used to evaluate the financial performance of public universities. These measures include liquidity, diversity of revenue collection, dependence on student fees, borrowings to equity ratio and operating result. Universities are non-profit making organizations but their operating result is a valuable measure of financial performance. Large deficits or a trend of successive deficits indicate a necessity for review and analysis.

Due to the compelling needs of organizational certifications, universities have had to install and implement effective internal controls to facilitate effective and efficient financial performance (Mungai, 2015). These preventive, detective, corrective and budgetary controls form the basis of internal controls and affect the financial performance of public universities. The reliability of financial performance is dependent on the efficiency of internal controls that provide efficiency in transactions, effective book keeping and adequate system authorization. In addition, it is important that institutions have good disclosure of the summarized accounting information (Mbroh, 2011). Internal control systems greatly influence the nature, type and quality of financial performance. Grant (2014) reiterated that when an organization has effective measures of performance, it is able to concentrate on achieving its goals and objectives.

\subsubsection{Global Perspective}

Today, most of the developing countries are producing organizations that are competing successfully with multinational giants of the most developed countries (Snell, 2012). As a result of globalization and the various economic and political reforms implemented by the developed world, there is the emergence of an impressive array of institutions of higher learning that have enhanced their systems with proper internal controls to enhance performance necessitating more research in public universities particularly in the developing world.

Many of these institutions have performed so well within their national borders that they have ventured into the international arena; they have become international universities. However, the transformation is not generally accompanied by a change in the way these organizations manage their budgets and internal control systems employed to safeguard their resources. A major challenge which globalization therefore poses to these organizations is how to manage these systems effectively within the international setting (Pamela et al., 2010).

Today, universities are witnessing unprecedented changes in the way they view performance in the face of 
increasingly global marketplace, with many organizations competing to outdo each other. As universities move towards a borderless environment, the ability to engage and develop better control systems to minimize risk are becoming increasingly important. In view of these changes, a number of trends, as identified by Rani (2014) are likely to have a significant impact on the financial performance of these universities.

\subsubsection{Regional Perspective}

Chancellors and Councils of Universities in Africa are focusing on improving the financial performance of their institutions, but it's becoming more difficult to enhance the financial performance in the face of heightened risk and fraud in these institutions that they have to deal with. Development and implementation of proper internal control systems has become top agenda for these leaders in most African states. Many upcoming universities in most African countries have lost their resources through fraud and outright theft by employees for not having proper internal control systems that could possibly prevent such losses (Garavan \& Heraty, 2016).

Muhammed (2014) conducted a critical analysis of internal control systems in Ethiopia and Tanzania. The study showed that both the Ethiopian and Tanzanian reforms have been successful in the implementation of internal control systems in institutions of higher learning. Both pathways were selective and focused on systematically addressing key weaknesses in financial controls. The first order task was to instill effective controls while the second order task was to improve the efficiency of controls. Both involved extensive customization. In comparing the two countries' in terms of their engagement of internal control systems, actions of Ethiopia have been on evolving existing systems, developing a hybrid approach, and focusing on the legal framework. According to Shanmugam, Haat and Ali, (2012), an adequate system of internal controls is vital for the proper management of universities, and an internal control system with procedures for evaluating the performance of the entity regardless of being profit or non-profit is very vital for ensuring that the institutions are in check.

\subsubsection{Kenyan Perspective}

The scandals of recent years emphasize the need to evaluate, scrutinize and reformulate control systems of checks and balances in order to guide corporate executives and persons in decision-making. Therefore, as much as an organization would like to implement appropriately derived control measures; it must also consider the amount of money involved in implementing such measures. The embezzlement of funds from public institutions or organizations, particularly in essential services and public institutions, is becoming more common. Such scandals have raised concerns about their internal control systems. Despite the lack of any reported financial scandals, there is a growing concern as to whether they experience the same deficiencies as other public regulatory institutions do. Recent reports on the mismanagement of funds in public universities in Kenya by the media coupled with exposure of the complex web of rot and poor control systems which was highlighted in the recent past by the work of an investigative journalist raises serious questions.

Several studies have been carried out on internal controls systems and performance in Kenya. According to Wanjohi (2013) the measurement and evaluation of financial performance is central to control, and addresses three questions namely; what happened, why it happened and what to do about it. Financial performance provides short term feedback to the control systems as they monitor the implementation of strategic objectives by checking the organization's position, communicating the position, confirming priorities and compelling progress (Simiyu 2011). It can therefore be interpreted that internal controls are the means while financial performance is the end.

\subsection{Statement of the Problem}

There is rising concern about financial performance in public universities in Kenya and the concern has become a national issue especially at this time that the government has reduced its financial support of these public institutions (Thugge, Heller, \& Kiringai, 2017). Internal control systems are set up by organizations to aid them in meeting their objectives, ensure generation of reliable financial reports, increase organizational compliance to financial regulations as well as prevent loss of organizational resources (Emasu, 2010). Active involvement and proper financial management of public universities by their leaders through the introduction of internal controls is likely to contribute positively to financial performance of these institutions. Despite the documented benefits of adopting such systems, it remains unclear if such systems significantly affect financial performance of public universities in Kenya.

Evidence from empirical literature by Ndiwa (2014) and Ndifon (2014) found that organizational internal controls and financial performance is an understudied area (Gerrit \& Abdolmohammadi, 2015). Their studies identified low liquidity ratios, untimely financial reporting, low accountability, frauds and mismanagement of 
funds in organizations that affected performance. Mohammed (2003) research on the effect of the internal controls of Ethiopian Airlines in Nairobi found that internal controls put in place did affect performance of the airline.

Previous studies concentrated on the relationship between internal controls and performance in various organizations and not on the effect of internal control systems on the financial performance of public universities in Kenya. Those that have attempted have majorly focused on internal control system and performance in various sectors with extant literature revealing divergence of thoughts (Kilemi et al., 2017). Despite the widespread recognition of the crucial role of internal control systems in influencing financial performance of public universities, the theoretical perspectives have neglected its combination with the internal institutions environment and the potential influence internal controls have on financial performance and this is a potentially serious omission (Ryals \& Davies, 2013). This study attempts to answer the question of whether internal control systems affect the financial performance of public universities in Kenya. It is against this background that this study was undertaken to address the research gap, and also provide a better understanding through empirical evidence of the effects of internal control systems on financial performance of public universities in Kenya.

\subsection{General Objective}

The general objective of the study was to investigate the effect of internal control systems on financial performance of public universities in Kenya

\subsubsection{Specific Objective}

Specific Objectives of the study was to investigate the effect of detective controls on financial performance of public universities in Kenya.

\subsubsection{Research Hypothesis}

$\mathrm{H}_{01}$ : There is no statistically significant effect of detective controls on the financial performance of public universities in Kenya.

\section{Literature Review}

A theory is a set of statements or principles devised to explain a group of facts or phenomena, especially one that has been repeatedly tested or is widely accepted and can be used to make predictions about a natural phenomenon. This study focused on two theories to explain the effect of independent variable on the dependent variable. These theories were; the Agency theory and the Attribution theory.

\subsection{Theoretical Review}

Agency theory was developed in 1976 by Jensen and Meckling. This theory is an agency relationship as a contract under which one or more persons (the principal) engages another person (the agent) to perform some service on their behalf which involves delegating some decision-making authority to the agent. Agency theory analyses the relationship between two parties: investors and managers. The agent (manager) undertakes to perform certain duties for the principal (investors) and the principal undertakes to reward the agent. According to the agency theory, a firm consists of a nexus of contracts between the owners of economic resources (the principals) and managers (the agents) who are charged with using and controlling those resources. The theory posits that agents have more information than principals and that this information asymmetry adversely affects the principals' ability to monitor whether or not their interests are being properly served by agents (Jensen \& Meckling, 1976).

As such, the theory describes firms as necessary structures to maintain contracts, and through firms, it is possible to exercise control which minimizes opportunistic behavior of agents (Mwangi, 2012). According to the theory, in order to harmonize the interests of the agent and the principal, a comprehensive contract is written to address the interest of both the agent and the principal. The agent-principal relationship is strengthened more by the principal employing an expert and systems in form of auditors and internal control systems to monitor the agent. Further the theory recognizes that any incomplete information about the relationship, interests or work performance of the agent described could be adverse and a moral hazard. Moral hazard and adverse selection impact on the output of the agent in two ways; not possessing the requisite knowledge about what should be done and not doing exactly what the agent is appointed to do. 
The agency theory therefore works on the assumption that principals and agents act rationally and use contracting to maximize their wealth (Jensen \& Meckling, 1976). This theory was applicable to this study because internal controls are one of many mechanisms used in business to address the agency problem by reducing agency costs that affects the overall performance of the relationship as well as the benefits of the principal. Internal control enhances the provision of additional information to the principal (shareholder) about the behavior of the agent (management) and reduces information asymmetry and lowers investor risk and low revenue. This theory lays more emphasis to the preventive controls objectives in the study.

Attribution theory is a social psychology theory that explores how people interpret events and behaviors and how they ascribe causes to the events and behaviors. According to Schroth and Shah (2000), studies using attribution theory examine the use of information in the social environment to explain events and behaviors. Reffett (2007) asserts that when evaluators believe comparable persons would have acted differently in a given circumstance, evaluators tend to attribute responsibility for an outcome to the person. On the other hand, when evaluators believe comparable persons would have acted similarly, they tend to attribute responsibility for the outcome to the situation. According to Wilks and Zimbelman (2004), the first case refers to internal or dispositional attributions while the second one refers to external or situational attributions.

Attribution theory thus advocates for accountants and auditors to report on the effectiveness of firms' internal control. Auditors and accountants are therefore expected to gain a better understanding of the internal controls in place, assess the design and implementation of the internal controls, and test the operating effectiveness of the internal controls. This is deemed necessary for their reliance and possibly scaling back of other substantive auditing and accounting procedures for the required financial statements generation. According to Bonner et al. (1998), evaluators can use the audit and accounting processes as a basis to determine negligence if they fail to detect internal control related fraud that may occur.

Despite growth in technology that has changed the internal control systems structure there is always a need for a person to manage these systems. As such it is upon such authority figures, that is, management and the University council who should ensure that all the relevant regulatory and compliance issues are adhered to. In reference to the study this theory sought accountants and auditors to be in the forefront of reporting fraud when it occurs. This theory was therefore relevant to the study in that it suggested that when fraud occurred, identified parties should be held accountable and auditors and accountants, being the "public watch dogs" are most likely to be held accountable if evaluators determine substandard audit and accounting services were provided. It emphasizes on detective controls.

\subsection{Empirical Review of detective Controls and Financial Performance}

Detective controls are internal controls designed to identify problems that already exist and attempt to detect undesirable acts. They are designed to search for and identify errors on a timely basis after they have occurred. They provide evidence that a loss has occurred but do not prevent a loss from occurring (Ellsworth, 2016). Audits are detective controls that supports an organization in complying with the critical laws and controls. Monthly reconciliation of bank accounts, review and verification of refunds, reconciliation of petty cash accounts, audits of payroll disbursements or conducting physical inventory are all detective controls (Walker, 2014).

Mugo (2015) sought to establish the relationship between detective controls and financial performance in Technical Training Institutions in Kenya. Controls were looked at from the perspective of control environment, internal audit and control activities whereas financial performance focused on liquidity, accountability and reporting as the measures of financial performance. The study found that management of the institutions is committed to the control systems, actively participates in monitoring and supervision of the activities of the Technical Training Institutions in Kenya, that the internal audit department is not efficient, is understaffed, doesn't conduct regular audit activities and doesn't produce regular audit reports although the few reports produced by the internal audit department address weaknesses in the system of control.

Using the analytical approach and focusing on control activities and monitoring, Barra (2014) investigated the effect of penalties and other internal controls on employee's propensity to be fraudulent. Data was collected from both managerial and non-managerial employees. The results showed that the presence of the control activities, separation of duties, increases the cost of committing fraud. Thus, the benefit from committing fraud has to outweigh the cost in an environment of segregated duties for an employee to commit fraud. The results suggest the effectiveness of preventive controls control activities such as segregation of duties is dependent on detective controls. 


\subsection{Conceptual Framework}

\section{Detective Controls \\ - Surprise cash counts. \\ - Physical inventory counts. \\ - Reconciliations. \\ - Review of university performance \\ - Internal audit}

Independent Variable

Figure 1.0: Conceptual Framework

3. Research Methodology

\subsection{Research Philosophy}

A research philosophy is a belief in which data about a phenomenon should be gathered, analyzed and used. According to Saunders et al. (2009) research philosophy is defined as the development of the research background and knowledge. This research study adopted positivism as its research philosophy. Positivists believe that reality is stable and can be observed and described from an objective viewpoint without interfering with the phenomena being studied.

\subsection{Research Design}

This study adopted a causal research design. Causal studies focus on an analysis of a situation or a specific problem to explain the patterns of relationships between variables (Cooper \& Schindler, 2013). This design was appropriate because the study sought to establish relationships among variables at only one point in time and data was collected across a large number of organizations at one point in time. This design was appropriate for the study because it enabled the researcher to conduct a profound examination of the context, processes, and interactions of a phenomenon as well as the precise measurement of attitudes and outcomes.

\subsection{Target Population}

According to Mugenda and Mugenda (2008) a population is a well-defined or set of people, services, elements and events, groups of things or households that are being investigated. The population may also be defined as a large collection of all subjects from where the sample is drawn (Saunders et al., 2009). Target population on the other hand can be portrayed as the components that meet certain criteria for incorporation in an investigation.

The target population for this study consisted of all public universities operating in Kenya as at November 2017. According to CUE (2017), there are 31 public universities, 6 public university constituent colleges, 18 private universities, and 5 private university constituent colleges in Kenya as at November 2017. The population of the study was composed of all the 37 public universities operating in Kenya, and will focus on the deputy vice chancellor finance, registrar finance and administration, ICT personnel, finance officers and internal auditors. The study focused on only one respondent from each category on every public university This made a total population of 185 respondents as summarized in table 3.1 below.

\section{Table 3.1: Target Population}

\begin{tabular}{llc}
\hline Position & & Number \\
\hline Deputy Vice Chancellor & Finance & 37 \\
Registrars & $\begin{array}{l}\text { Administration } \\
\text { Finance }\end{array}$ & 37 \\
ICT personnel & & \\
Finance officers & & 37 \\
Internal auditors & & 37 \\
Total & & 37 \\
\hline
\end{tabular}




\subsection{Sample Size and Sampling Technique}

Sampling is a procedure of using a small number of items or part of the whole population to make conclusions regarding the population. It enables the researcher to estimate some unknown characteristics of the population and make generalization (Zikmund et al., 2013). According to Kothari (2011), sampling may be defined as the selection of parts of an aggregate or totality on the basis of which judgment or inference about the aggregate or totality is made. Stratified random sampling technique was used to come up with the sample.

To obtain the desired sample size for the study with the population of 34 public universities, Yamane Taro (1967) formula was used as shown;

$$
n=\frac{N}{1+N\left(e^{2}\right)}
$$

Where $\mathrm{n}$ is the sample size

$$
\begin{aligned}
& \mathrm{N} \text { is the population (37) } \\
& e \text { is the sampling error at } 0.05
\end{aligned}
$$

It was assumed that all the attributes measured were normally distributed or nearly so and the confidence level is $95 \%$ and the estimated variation of response is $50 \%$. The precision level was taken at $5 \%$.

Therefore;

$$
n=\frac{07}{1+37\left(0.05^{2}\right)}
$$

Sample size was therefore 34 public universities in Kenya.

\subsection{Data Collection Technique and Instrument}

Data collection is the process of gathering and measuring information on variables of interest, in an established systematic fashion that enables one to answer stated research questions, test hypotheses, and evaluate outcomes (Cooper \& Schindler, 2013). This study collected both primary and secondary data and used a research questionnaire as the main tool of data collection. Primary data was collected by use of structured (closed-ended) and unstructured (open-ended) questionnaires that captured the various variables of the study. Secondary data was collected through evaluation of reports, organizational journals, publications and review of information from the organizations websites.

\subsection{Pilot Test}

In order to test to improve the validity of the instruments, the researcher first pre-tested the questionnaire in a pilot study. The questionnaire was piloted on five public University in Kenya in order to establish whether the questions there in measure the expected theorized variables in the conceptual framework. This was generally supported by Mugenda and Mugenda (2003) who indicated that successful pilot study uses $1 \%$ to $10 \%$ of the actual sample size. These five universities used in the pilot study were not included in the final study.

\subsection{Data Analysis}

Quantitative data was analyzed using Statistical Package for Social Sciences (SPSS) Version 22. All the questionnaires received were referenced and items in the questionnaire coded to facilitate data entry. Confirmatory Factor analysis (CFA) was conducted to make a prediction about the dependent variable based on its covariance with all the concerned independent variables. Pearson correlation coefficient was used to determine the strength and the direction of the relationship between the dependent variable and the independent variable. The analysis using Pearson correlation coefficient was based on the assumption that the data was normally distributed and also because the variables were continuous. Multiple regression analysis is used to determine whether a group of variables together predict a given dependent variable (Tracy, 2012). Therefore, multiple linear regressions was used to obtain an equation which described the dependent variable in terms of the independent variables based on the regression model. The Analysis of Variance (ANOVA) was used to test for the goodness of fit of the models and significance of the relationship between the dependent and independent variable based on a $5 \%$ level of significance. The regression model generally assumed the following equation;

$\mathrm{Y}=\beta_{0}+\beta_{1} \mathrm{X}_{1}+\varepsilon$ where: -

$\mathrm{Y}=$ represents the dependent variable, financial performance

$\beta_{0}=$ constant 
$\mathrm{X}_{2}=$ Detective Controls

$\varepsilon=$ Error Term

\subsection{Results and Discussion}

\subsection{Pilot Test and Reliability}

A pilot study was conducted before the main study to check the problem areas and possible confusion that may be associated with the survey. The pilot study was also to standardize the measuring instrument and improve its the validity. First, the instrument was discussed with supervisors and then pre-tested with 5 senior employees from 5 different universities. This is generally supported by Mugenda and Mugenda (2013) who indicate that successful pilot study uses $1 \%$ to $10 \%$ of the actual sample size.

To measure the reliability of the data collection instrument, Cronbach alpha was calculated for Likert scale questions of the questionnaire. Internal consistency was relevant to this study because the instruments were measuring the same thing. Cronbach's alpha was used to measure internal consistency. The cronbach's alpha is a statistic calculated from the pairwise correlations between items, and the results range between zero and one (Mugenda \& Mugenda, 2013). Cronbach Alpha statistic for this study was 0.842 and was considered adequate for this study.

\subsection{Study Response Rate}

The study targeted a sample size of 185 respondents of which 160 filled in and returned the questionnaires making a response rate of $86.4 \%$ as depicted by the frequency distribution table 2 below. This response rate was satisfactory to make inferences and conclusions for this study. According to Mugenda \& Mugenda (2013), a response rate of $50 \%$ is considered adequate for analysis and reporting, $60 \%$ is rated good while any response rate over $70 \%$ is considered to be an excellent response rate.

Table 2: Study's Response Rate Frequencies

\begin{tabular}{lll}
\hline Response & Frequency & Percent \\
\hline Successful & 160 & 86.4 \\
Unsuccessful & 25 & 13.6 \\
Total & 185 & 100 \\
\hline
\end{tabular}

4.3Dist

ribution of the Respondents by Gender

The respondents were asked to state their gender. The study established that majority of the respondents as shown by the figure below, $52.6 \%$ were male whereas $47.4 \%$ of the respondents were female. This implies that respondents were well distributed in terms of their gender and thus the findings of this study did not suffer from gender biasness.

Table 3: Distribution of Respondents by Gender

\begin{tabular}{|lll|}
\hline Gender & Frequency & Percentage \\
Male & 85 & $52.6 \%$ \\
Female & 75 & $47.4 \%$ \\
Total & 160 & $100 \%$ \\
\hline
\end{tabular}

\subsection{Distribution of Respondents by Education Level}

The respondents were asked to indicate their level of education. The study established that, $32.1 \%$ of the respondents were post graduate holders, $44.9 \%$ of the respondents were degree holders, $21.8 \%$ of the respondents held diploma certificates whereas $1.2 \%$ of the respondents held secondary certificates. This was highly expected since the respondents were at management level where the skills knowledge and competencies are expected to be high. This depicted that the respondents were well educated and informed and therefore furnished this study with better information which added value to the objectives of the study. 


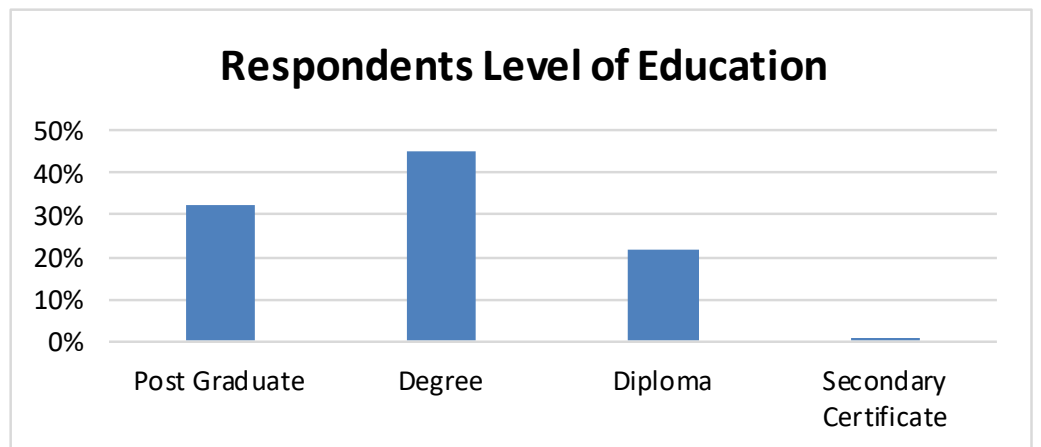

Figure 2: Level of Education

\subsection{Descriptive results for Detective Controls}

The second objective of the study was to assess the effects of detective controls on financial performance of public universities in Kenya. Respondents' opinions on the influence of detective controls on the financial performance in public universities in Kenya are given in Table 4.9 below.

Table 4: Influence of Detective Controls on Financial Performance

\begin{tabular}{|c|c|c|c|c|c|c|c|}
\hline Statement & SA(\%) & $\mathbf{A}(\%)$ & $\mathbf{N}(\%)$ & $D(\%)$ & $\operatorname{SD}(\%)$ & Mean & SD \\
\hline $\begin{array}{l}\text { My organization conducts surprise cash } \\
\text { counts on all the employees handling cash. }\end{array}$ & 41.5 & 45.5 & 11.7 & 1.3 & $\mathbf{0}$ & 4.27 & 0.72 \\
\hline $\begin{array}{l}\text { There are physical inventory counts in all } \\
\text { departments to detect inconsistencies. }\end{array}$ & 37.3 & 48.5 & 12.3 & 1.9 & $\mathbf{0}$ & 4.21 & 0.73 \\
\hline $\begin{array}{l}\text { Reconciliations at the end of every period } \\
\text { are conducted to detect areas having } \\
\text { balances. }\end{array}$ & 44.1 & 39.7 & 13.8 & 1.5 & 0.9 & 4.52 & 0.36 \\
\hline $\begin{array}{l}\text { Internal reviews of compliance of internal } \\
\text { controls in units are conducted periodically }\end{array}$ & 48.2 & 39.7 & 9.4 & 1.8 & 0.9 & 4.31 & 0.83 \\
\hline $\begin{array}{l}\text { Management has assigned responsibilities } \\
\text { for the timely review of audit reports and } \\
\text { any non-compliance items noted in those } \\
\text { audit reports. }\end{array}$ & 39.9 & 48.4 & 9.4 & 2.3 & $\mathbf{0}$ & 4.13 & 0.77 \\
\hline $\begin{array}{l}\text { Internal audit evaluate and contribute to the } \\
\text { improvement of risk management, control } \\
\text { and governance using a systematic and } \\
\text { disciplined approach. }\end{array}$ & 32.1 & $\mathbf{5 3 . 0}$ & 12.2 & 2.8 & $\mathbf{0}$ & 4.12 & 0.82 \\
\hline $\begin{array}{l}\text { Management is committed to the ethical } \\
\text { values in the operation of the systems within } \\
\text { the university. }\end{array}$ & 34.2 & 52.2 & 10.8 & 1.3 & 1.4 & 4.16 & 0.78 \\
\hline $\begin{array}{l}\text { Management has a criteria for detection of } \\
\text { which risks to the university are most } \\
\text { critical. }\end{array}$ & 40.4 & 43.4 & 13.4 & 2.8 & 0 & 4.20 & 0.78 \\
\hline $\begin{array}{l}\text { There are independent process checks and } \\
\text { evaluations of controls activities on ongoing } \\
\text { basis. }\end{array}$ & 9.6 & 41.3 & 34.8 & 8.7 & 5.6 & 3.41 & 0.97 \\
\hline $\begin{array}{l}\text { Management control method is conducted } \\
\text { regularly and is adequate to investigate } \\
\text { unusual activities in the university. }\end{array}$ & 39.6 & 47.8 & 10.6 & 2.0 & $\mathbf{0}$ & 4.25 & 0.72 \\
\hline
\end{tabular}


Internal audits are carried out twice a year to

detect areas with internal weaknesses.

Internal audit findings are reported directly

to top management and the audit and risk sub-committee of the board.

The university has a monitoring system that identifies potential Risks and threats and provides appropriate actions to be taken.

Internal audit findings are acted on immediately.

The university has developed a tool and mechanisms for detecting fraud by its employees.

There is a quarterly review of performance by the university to detect areas that are not at par with the set objectives.

All the staff in our institution are aware of the internal control measures by the university to prevent fraud.

Average

40.7

34.6

11.7

0.9

$\mathbf{0}$

4.27

0.70

\title{
54
}

\section{8.}

2.4

$\mathbf{0}$

4.21

0.70

39.3

44.8

29.9

58.4

8.4

14.3

1.4

0.2

4.20

0.84

31.0

54.

45.2

$$
42.7
$$

38.3

47.5

13.3

12.1

3.3

0

$\begin{array}{ll}4.12 & 0.78\end{array}$

4.1

1

0

$\begin{array}{ll}4.13 & 0.82\end{array}$

\section{8}

47.5

\begin{abstract}
12.7
\end{abstract}
2.4

0.5

4.18

0.76

Findings revealed that majority of the respondents with $84.3 \%$ were of the view that detective controls helps organizations with preventing loss through detecting fraud before it happens, $12.7 \%$ were neutral to the statement, whereas $2.9 \%$ were not in agreement. These findings were in agreement with those of Ondieki (2015) who emphasized that managers should communicate their internal controls to their employees so as to improve on operational efficiency and ensure accurate financial reporting during internal or external audits.

\subsection{Quantitative Analysis for Detective Controls}

\subsubsection{Correlation Test for Detective Controls}

Table 4.5 Relationship between Detective Controls and Financial Performance

\begin{tabular}{|c|c|c|c|}
\hline Variable & & Detective Controls & $\begin{array}{l}\text { Financial } \\
\text { Performance }\end{array}$ \\
\hline Detective Controls & $\begin{array}{l}\text { Pearson Correlation } \\
\text { Sig. (2-tailed) }\end{array}$ & 1 & \\
\hline $\begin{array}{l}\text { Financial Performance } \\
* * \text {. Correlation is signif }\end{array}$ & $\begin{array}{l}\text { Pearson } \\
\text { Correlation } \\
\text { Sig. (2-tailed) } \\
\text { cant at the } 0.01 \text { level (2-tailed) }\end{array}$ & $\begin{array}{l}.692 \\
.672\end{array}$ & 1 \\
\hline
\end{tabular}

Table 4.5 displays the results of correlation test analysis between the dependent variable and the independent variable. Results on Table 4.10 above show that detective controls were positively correlated with financial performance by a Pearson's product moment correlation factor of 0.692 . This reveals that any positive change in detective controls would translate into improved financial performance. 


\subsubsection{Model Summary for Detective Controls}

Table 4.6 Model Summary for Detective Controls

\begin{tabular}{lllll}
\hline Model & R & R Square & $\begin{array}{l}\text { Adjusted } \\
\text { Square }\end{array}$ & R $\begin{array}{l}\text { Std. Error of the } \\
\text { Estimate }\end{array}$ \\
\hline 1 & $.908^{\mathrm{a}}$ & .831 & .801 & .059 \\
\hline
\end{tabular}

a. Predictors: (Constant), Detective Controls

Regression analysis was conducted to empirically determine whether detective controls were significant in determining the financial performance of public universities in Kenya. Regression results in Table 4.11 indicate the goodness of fit for the regression between detective controls and financial performance was strong. An $\mathrm{R}$ squared of 0.831 indicates that $83.1 \%$ of the variances in financial performance are explained by the variances in detective controls. The correlation coefficient of $90.8 \%$ indicates that the combined effect of the predictor variables has a very strong and positive correlation with financial performance.

\subsubsection{ANOVA for Detective Controls}

Table 4.7 ANOVA for Detective Controls

\begin{tabular}{lllll}
\hline Indicator & Sum of Squares & Mean Square & F & Sig. \\
\hline Regression & 5.466 & 5.416 & 13.917 & .000 \\
Residual & 37.180 & 0.386 & & \\
Total & $\mathbf{4 2 . 6 4 6}$ & & & \\
\hline
\end{tabular}

Findings in Table 4.7 show the $\mathrm{F}$ statistic. The $\mathrm{F}$ value indicates whether the set of independent variables as a whole contribute to the variance in the dependent variable. An F value of 13.917 was found. Findings in Table 4.12 further show that the $\mathrm{F}$ value was significant $(\mathrm{p}=0.000)$ at $95 \%$. This means that detective controls were significant in predicting financial performance in public universities in Kenya.

\subsubsection{Regression Coefficient for Detective Controls}

Table 4.8 Regression Coefficient for Detective Controls

\begin{tabular}{lllll}
\hline Variable & Beta & Std. Error & t & Sig. \\
\hline Constant & 3.132 & 0.317 & 9.825 & .000 \\
& 0.237 & 0.073 & 3.792 & .000 \\
Detective Controls & & & & \\
\hline
\end{tabular}

Table 4.8 displays the regression coefficients of the independent variable. From the above regression model shown in table 4.13, detective controls and financial performance to a constant zero, financial performance would be 3.132. It is established that a unit increase in detective controls would cause an improvement in financial performance by a factor of 0.237 . This clearly shows that there is a positive relationship between detective controls and financial performance. P-value was less than 0.05 , which shows that variables covered in the study on detective controls were statistically significant to influence financial performance. The results therefore reveal that detective controls are statistically significant in explaining financial performance in public universities in Kenya.

The study concluded that since detective controls significantly affected financial performance, it was good enough to fail to accept the null hypothesis which states that; $\mathrm{H}_{02}$ : There is no statistically significant effect of detective controls on the financial performance of public universities in Kenya. The hypothesis was therefore 
rejected.

\subsection{Descriptive Results for Financial Performance}

The study sought information on financial performance of public universities in Kenya. Respondents' opinions on financial performance in public universities in Kenya are given in Table 9 below.

Table 4.9: Descriptive Results for Financial Performance

\begin{tabular}{|c|c|c|c|c|c|c|c|}
\hline Statement & SA(\%) & $\mathbf{A}(\%)$ & $\mathbf{N}(\%)$ & $D(\%)$ & SD(\%) & Mean & $\begin{array}{l}\text { Std. } \\
\text { Dev }\end{array}$ \\
\hline $\begin{array}{l}\text { Internal control systems focus on improving } \\
\text { the universities financial performance }\end{array}$ & 41.6 & 50.2 & 6.4 & 1.0 & 0.8 & 4.29 & 0.73 \\
\hline $\begin{array}{l}\text { Adherence to set regulations on internal } \\
\text { control systems positively contributes to } \\
\text { financial performance of the university. }\end{array}$ & 42.5 & 49.0 & 5.2 & 2.9 & 0.4 & 4.23 & 0.74 \\
\hline $\begin{array}{l}\text { Internal control systems improve the } \\
\text { company's efficiency and effectiveness that } \\
\text { in turn improves financial performance. }\end{array}$ & 47.5 & 41.9 & 8.7 & 1.5 & 0.4 & 3.33 & 0.76 \\
\hline $\begin{array}{l}\text { Internal control systems allow the } \\
\text { University to have self-financing capability, } \\
\text { hence financial stability. }\end{array}$ & 29.6 & 43.3 & 9.8 & 12.2 & 5.1 & 3.22 & 0.71 \\
\hline $\begin{array}{l}\text { Good internal control systems bring about } \\
\text { improved systems and resources. }\end{array}$ & 32.6 & 51.5 & 8.7 & 6.3 & 0.9 & 4.12 & 0.81 \\
\hline $\begin{array}{l}\text { Efficiency of expenditures is realized } \\
\text { through good internal control systems. }\end{array}$ & 29.4 & 58.3 & 4.1 & 5.8 & 2.4 & 4.15 & 0.77 \\
\hline $\begin{array}{l}\text { Internal controls are responsible for proper } \\
\text { asset management. }\end{array}$ & 35.3 & 48.7 & 9.7 & 4.4 & 1.9 & 3.11 & 0.71 \\
\hline $\begin{array}{l}\text { The university's asset base has greatly } \\
\text { increased over time. }\end{array}$ & 40.8 & 47.2 & 7.2 & 2.8 & 2.0 & 4.29 & 0.76 \\
\hline $\begin{array}{l}\text { The university is always able to meet its } \\
\text { current obligations in a timely manner. }\end{array}$ & 45.3 & 43.7 & 9.1 & 1.4 & 0.5 & 4.30 & 0.77 \\
\hline $\begin{array}{l}\text { Financial reporting is always done on a } \\
\text { timely basis. }\end{array}$ & 39.9 & 47.9 & 8.3 & 2.9 & 1.0 & 3.24 & 0.84 \\
\hline $\begin{array}{l}\text { The university has the ability to internally } \\
\text { fund business ventures instead of using } \\
\text { external sources. }\end{array}$ & 42.2 & 35.2 & 10.8 & 9.8 & 2.0 & 3.20 & 0.86 \\
\hline $\begin{array}{l}\text { There has been improvement in return on } \\
\text { assets over the years }\end{array}$ & 44.7 & 45.5 & 7.6 & 2.2 & 0.0 & 3.27 & 0.77 \\
\hline $\begin{array}{l}\text { The university has enough cash to meet its } \\
\text { obligations effectively (as and when they } \\
\text { fall due). }\end{array}$ & 35.6 & 31.3 & 12.8 & 10.2 & 10.1 & 3.10 & 0.87 \\
\hline $\begin{array}{l}\text { Cost reduction as a measure has a direct } \\
\text { effect on the financial performance of the } \\
\text { university. }\end{array}$ & 32.4 & 55.3 & 5.1 & 5.8 & 1.4 & 4.13 & 0.77 \\
\hline $\begin{array}{l}\text { Proper internal control systems in the } \\
\text { university lead to Improved Systems and } \\
\text { Resources. }\end{array}$ & 35.5 & 53.2 & 6.1 & 4.9 & 0.3 & 4.12 & 0.78 \\
\hline Average & 38.3 & 46.8 & 8.0 & 4.9 & 2.0 & 3.74 & 0.77 \\
\hline
\end{tabular}


The study sought to investigate whether Internal control systems focus on improving the universities financial performance. Findings revealed that majority of the respondents with $91.8 \%$ (mean 4.29 , std. dev 0.73 ) were in agreement with the statement, $6.4 \%$ of the respondents were neutral to the statement, whereas $1.8 \%$ of the respondents were not in agreement with the statement that internal control systems focused on improving the universities financial performance.

\subsubsection{Quantitative Analysis for Financial Performance}

Pearson product moment correlation was conducted to determine the strength of relationship between the study variables provided in Table 10 below.

Table 4.10: Pearson product moment correlation

\begin{tabular}{llll}
\hline Variables & & $\begin{array}{l}\text { Financial } \\
\text { Performance }\end{array}$ & $\begin{array}{l}\text { Detective } \\
\text { Controls }\end{array}$ \\
\hline $\begin{array}{l}\text { Financial } \\
\text { Performance }\end{array}$ & $\begin{array}{l}\text { Pearson } \\
\text { Correlation } \\
\text { Sig. (2tailed) }\end{array}$ & 1 & \\
& N & 160 & \\
Detective & Pearson & $.654^{* *}$ & 1 \\
Controls & Correlation & & \\
& Sig. (2tailed) & .000 & 160 \\
& $\mathrm{~N}$ & 160 &
\end{tabular}

From the findings on the correlation analysis between financial performance and internal control systems, the study found a positive significant correlation between detective controls and financial performance as shown by correlation coefficient of 0.654 .

\subsubsection{Combined Effect of Internal Control Systems on Financial Performance}

Table 4.11: Model Summary for Internal Control Systems

\begin{tabular}{llccc}
\hline Model & R & R Square & Adjusted R Square & Std. Error of the Estimate \\
1 & $0.873 \mathrm{a}$ & 0.72 & 0.52 & 0.896 \\
\hline
\end{tabular}

The $\mathrm{R}$ value of 0.873 means that there was a strong correlation between independent variables (preventive controls, detective controls, corrective controls, budgetary controls, regulations and policies) and the dependent variable (financial performance) of public universities in Kenya. The $\mathrm{R}^{2}$ value of 0.72 means that $72 \%$ of performance can be explained by public universities preventive controls, detective controls, corrective controls, budgetary controls, regulations and policies.

Table 4.12: ANOVA for Internal Control Systems

\begin{tabular}{llllllll}
\hline Model & & $\begin{array}{l}\text { Sum } \\
\text { Squares }\end{array}$ & of & df & $\begin{array}{l}\text { Mean } \\
\text { Square }\end{array}$ & F & Sig. \\
1 & Regression & 10.345 & 5 & 2.836 & 23.445 & 0.010 \\
& Residual & 28.331 & 90 & 0.823 & & \\
& Total & 38.676 & 95 & & & \\
\hline
\end{tabular}

The findings showed that the $\mathrm{F}$ value of 23.445 was significant $(\mathrm{p}=0.010)$ at $95 \%$ confidence level. This meant that the model was significant for predicting performance of public universities in Kenya. 
Table 4.13: Regression Coefficients for Internal Control Systems

\begin{tabular}{lllllll}
\hline Model & \multicolumn{2}{l}{ Unstandardized Coefficients } & Standardized Coefficients & t & Sig. \\
& & B & Std. Error & Beta & & \\
1 & $($ Constant) & 2.345 & 0.431 & & 5.439 & 0.000 \\
\cline { 3 - 7 } & 0.589 & 0.076 & 0.157 & 1.977 & 0.040 \\
$\begin{array}{l}\text { Detective } \\
\text { Controls }\end{array}$ & & & & &
\end{tabular}

The coefficients Table 4.13 provides the necessary information to predict performance from the internal determinants of preventive controls in public universities. Findings showed that preventive controls were statistically significant as their p-values were less than 0.05 . This means that the variables were important predictors of financial performance. These findings concurred with those of Jayamaha (2014) who asserted that the internal controls process is one of the most productive and useful management accounting techniques that organizations use to enhance performance in institutions of higher learning.

According to Silva and Jayamaha (2014), there exists a strong relationship between the internal control systems employed and the financial performance of organizations, and public universities are no exception. These findings also concurred with those of Chege (2013) who established a positive influence of controls on the financial performance of public universities in Kenya.

The New model therefore is;

$\mathrm{Y}=2.345+0.589 \mathrm{X}_{2}$

The new model indicated that without the internal control systems, the financial performance of public universities in Kenya would be 2.345 . The findings also showed that a unit change in preventive controls would influence the financial performance of public universities in Kenya by 0.589 .

\subsection{Discussion of Findings 5.1 Summary of Findings}

Regression analysis was conducted to empirically determine whether detective controls were significant in determining the financial performance of public universities in Kenya. Regression results indicated the goodness of fit for the regression between detective controls and financial performance was strong. An $\mathrm{R}$ squared of 0 . 831 indicates that $83.1 \%$ of the variances in financial performance are explained by the variances in detective controls. The correlation coefficient of $90.8 \%$ indicated that the combined effect of the predictor variables has a very strong and positive correlation with financial performance. An F value of 13.917 was found and was significant $(\mathrm{p}=0.000)$ at $95 \%$.

From the regression model, detective controls and financial performance to a constant zero, financial performance would be 3.132. It was established that a unit increase in detective controls would cause an improvement in financial performance by a factor of 0.237 . This clearly showed that there was a positive relationship between detective controls and financial performance. P-value was less than 0.05, which showed that variables covered in the study on detective controls were statistically significant to influence financial performance. The results therefore revealed that detective controls were statistically significant in explaining financial performance in public universities in Kenya. Based on these findings, the null hypothesis which stated that; There is no statistically significant effect of detective controls on the financial performance of public universities in Kenya, was therefore rejected.

\subsection{Conclusion}

The study concluded that detective controls had a positive and significant influence on the financial performance of public universities in Kenya. Aspects of detective controls such as conducting surprise cash counts, physical inventory counts, conducting reconciliations at the end of the period, having internal reviews of compliance of internal controls, and having management that was committed to ethical values all had an influence on the financial performance of public universities in Kenya. 


\section{References}

Abdi, C. (2015). Some characteristics of successful executives. Personnel Journal of Management, 50(6), 169213.

Anderson, M. (2012). The influence of creative accounting on the credibility of accounting reports. Journal of Financial Reporting and Accounting, 16 (2), $292-310$.

Armstrong, M. (2014). Armstrong's performance management toolkit (6th ed.). St. Louis, USA: Kogan Page Publishers

Akalu E. (2018). Evaluation of internal controls. Internal Research Journal of Finance and Economics, 27 (1), 124-144.

Boudreau, J., \& Cascio, W. (2012). Short introduction to strategic human resource management. (1st Ed.) New York, USA: Cambridge University Press.

Cooper, J., \& Schindler, M. (2012). Research design, qualitative, quantitative and mixed methods approaches, (3rd Ed.), Sage Publication USA.

Chege, B. (2013). Influence of leadership positions on internal controls and reported fraud in religious organizations, Journal of Forensic \& Investigative Accounting, 5(1), 85-125.

Davis, J., Schoorman, D., \& Donaldson, L. (2007). Stewardship theory and psychology. Academy of Management Review, 22 (1), 20-47.

Dixit, M. (2013). Internal controls systems in the US churches. An examination of the effect of church size and denomination on systems of Internal Controls. Accounting, Auditing \& Accountability Journal, 12(2), $142-163$.

Emasu, J. (2010). Measuring the efficiency and effectiveness of a nonprofit's performance, Strategic Finance Journal, 23(2), 271-314.

Garavan, C., \& Heraty, F. (2016). Does agency theory provide a general framework for audit pricing? International Journal of Auditing, 8 (2), 253-262.

Jensen, M., \& Meckling, W. (1976). Theory of the firm: managerial behavior and agency. (6th Ed.). St. Louis, USA: Kogan Page Publishers.

Jayamaha, H. (2016). Effect of budgeting process on budget the performance of state corporations in Kenya: a case of Kenyatta national hospital, International Academic Journal of Human Resource and Business Administration, 2(3), 225-281.

Katua, N. (2014). The role of SME's in employment creation and economic growth in selected countries. International Journal of Education and Research, 12(2), 461- 472.

Kennedy, J., Tennet, B., \& Gibson, B. (2016). Financial management practices in small businesses. regional \& metropolitan small enterprises research. The Journal of Seaanz, 14 (1), 55 - 63.

Kumar, K. (2011). Effect of risk management strategies on project performance of small and medium information communication technology enterprises in Nairobi, Kenya. International Journal of Economics, Commerce and Management, 2(3), 1-30.

Mwangi, J. (2015). Study of tax system impact on the growth of Small and Medium Enterprises (SMEs): With reference to Shinyanga Municipality, Tanzania, International Journal of Management \& Business Studies, 3(2), 99-105.

Muraleetharan, P. (2013). Activities and performance of organizations (special reference in Jaffna district). International Journal of Marketing, Financial Services \&Management Research, 4(2), 10-16.

Magara, Y. (2013). Financial intermediaries versus financial markets: A South African experience", International Business and Economic Research Journal, 10(2), 77-84.

Ogundipe, S., Idowu, A., \& Ogundipe, L. (2012). Working capital management firms' performance and market valuation in Nigeria. World Academy of Sciences, 61 (1), 1196 - 1200.

Pamela, H., Kusa, G. (2013). Determinants of financial performance of commercial banks in Kenya, International Journal of Economics and Financial Issues, 3(1), 237-252.

Stephen, S. (2017). Understanding effective cash management. Journal of Corporate Accounting, 34 (6), 89 - 98.

Snell, D. (2012). An effective internal controls system as an antidote for distress in the banking. Journal of Economics and International Business Research, 1(5), 106-121.

Terziovski, A. (2010). Decomposition of fraud-risk assessments and auditors' sensitivity to fraud cues. Contemporary Accounting Research, 21(3), 719-723.

Wallage, T. (2009). A. (2010). The oxford handbook of participation in organizations. (1st Ed.). New York, USA: Oxford University Press.

Vian, N. (2012). Budgetary process and organizational performance of apparel industry in Sri Lanka, Journal of Emerging Trends in Economics and Management Sciences, 3(4): 354-360. 